\title{
Counting Shadows - Measuring trafficking in Persons in Australia
}

\author{
Matthew Wise ${ }^{1}$ and Andreas Schloenhardt ${ }^{2, *}$
}

\author{
${ }^{1}$ The University of Queensland (UQ), Brisbane, Australia \\ ${ }^{2}$ The University of Queensland School of Law and University of Vienna, Department of Criminal Law and \\ Criminology, Vienna, Austria
}

\begin{abstract}
The true extent and nature of trafficking in persons in Australia remains a mystery despite wild speculations about the scale of this problem. This article aims to dispel some of the confusion surrounding trafficking in persons by examining the claims made about the prevalence of this offence and displacing many of the myths about the number of victims in Australia. This involves an analysis of the Australian Government's approach to data collection and a critical examination of the data provided by non-official sources, especially non-governmental organisations and advocacy groups. The article also investigates the 'dark figure' of trafficking in persons in Australia and concludes by developing recommendations to measure trafficking in persons in Australia more accurately and by offering directions for further research in this field.
\end{abstract}

Keywords: Trafficking in persons, Australia, dark figure of crime, trafficked persons.

\section{INTRODUCTION}

In the eleven years since the Australian Government first presented a national Action Plan to Eradicate Trafficking in Persons, a plethora of government papers, scholarly articles, and reports by international and non-governmental organisations (NGOs) have been produced in order to document and analyse the levels and characteristics of trafficking in persons in this country. Over the same period, the Australian Government has set up a comprehensive framework to assist and protect victims of trafficking persons and has frequently amended the offences relating to trafficking in Divisions 270 and 271 of the Criminal Code (Cth), most recently with the Crimes Legislation Amendment (Slavery, Slavery-like Conditions, and People Trafficking) Act 2013 (Cth).

But despite an ever-increasing number of books, articles, reports, and papers on the topic, the true extent of trafficking in persons in Australia remains unknown and poorly researched. There are no complete and accurate statistics that document the actual levels of this crime. Few cases of trafficking in persons come to the attention of Australian law enforcement agencies each year and due to the clandestine nature of this phenomenon, many instances of trafficking seemingly leave no more evidence than a momentary shadow.

Despite the absence of reliable, quantitative data, a great number of authors and organisations speculate

*Address correspondence to this author at The University of Queensland School of Law and University of Vienna, Department of Criminal Law and Criminology, Vienna, Austria; E-mail: a.schloenhardt@law.uq.edu.au about the scale of the 'trafficking problem' in Australia. There is great disparity between the figures published in various government, academic, and NGO documents. Many sources fail to adopt a sound methodology or do not include a sufficiently large sample size to generate meaningful data while other sources fail to disclose their methodology altogether (Schloenhardt, Beirne and Corsbie 2009). Much of the available data is the result of guesswork rather than thorough, analytical study. Australian research into trafficking in persons has so far failed to grasp the actual extent of the problem (Larsen and Renshaw 2012).

This article explores the challenges of measuring trafficking in persons and examines the available data from Australia. It outlines similar analyses conducted by other authors abroad, and attempts to develop a methodology to provide insight into the true extent of trafficking in persons in Australia. The goal here is not to generate exact figures about the number of victims, perpetrators, and cases, but to provide insight into the challenges of research in this field, critically analyse the work undertaken by other scholars, and articulate the parameters to measure trafficking in persons in Australia more accurately. This is important in order to evaluate and improve Australia's national response to trafficking in persons. Indeed, the lack of any official mechanism in Australia to estimate the full extent of the country's trafficking in persons problem has been repeatedly noted as a barrier to the evaluation and success of Government policies on this issue (Australian National Audit Office 2009; Australia. Attorney-General's Dept. 2013 (1 January-30June)). 


\section{THE THREE PROBLEMS OF MEASURING TRAFFICKING IN PERSONS}

Trafficking in persons is a notoriously clandestine crime. ${ }^{1}$ This is true both for the secretive conditions under which the crime is perpetrated and the imprecise means by which it is understood, with many unable to distinguish trafficking in persons from other migrationrelated offences (Aronowitz 2010; Larsen and Renshaw 2012; Schloenhardt and Jolly 2013). Interpretations of the term trafficking in persons and debates about what it is, what it is not, and what ought to be classified as trafficking persist, with many advocates and organisations applying their own agenda and ideology when using the term.

These factors complicate the understanding of the trafficking phenomenon and make comparison of data from different sources almost impossible. As later parts of this article will show, this also raises questions about the motivating factors of some publications in this field and their ability to present reliable and objective information. For these reasons, the task of yielding accurate research and forming some kind of consensus regarding estimates, statistics, and figures of trafficking in persons is barred by three, largely indistinct, problems.

The first is a practical problem caused by the complex and clandestine nature of the crime itself that often renders traditional methods of research in effective. Low levels of confirmed cases of trafficking in persons may be reflective of the fact that the more sophisticated cases never come to the foreor may be symptomatic of the inability, or unwillingness, of many victims to self-identify (Carrington and Hearn 2003). These problems are responsible for the existence of a substantial 'dark figure' of trafficking victims and perpetrators, especially in cases that diverge from the norm and thus prevent a targeted response from law enforcement.

The second problem concerns theoretical failures in the approaches taken to collect data, count instances of trafficking, and quantify the extent of trafficking in

\footnotetext{
${ }^{1}$ The internationally accepted definition of trafficking in persons is set out the United Nations (UN) Protocol to Prevent, Suppress and Punish Trafficking in Persons, especially Women and Children opened for signature 12 December 2000, 2237 UNTS 319 (entered into force 25 December 2003) [hereinafter Trafficking in Persons Protocol]. Article 3(a) of the Protocol defines the term as 'the recruitment, transportation, transfer, harboring or receipt of persons, by means of the threat or use of force or other forms of coercion, of abduction, of fraud, of deception, of the abuse of power or of a position of vulnerability or of the giving or receiving of payments or benefits to achieve the consent of a person having control over another person, for the purpose of exploitation.'
}

persons in Australia. A reliance on data relating to official, documented instances of trafficking-a method used in Australian Government reports-fails to take into account unreported cases, resulting in figures that are unrealistically low. Conversely, the use of guesstimates and arbitrary numbers-as done in some NGO reports-tends to overestimate and mischaracterise the crime's true dimensions. Most troubling is the frequent challenge of comparing research from different sources and the shortcomings in research methodology or incomplete explanations of the derivation of statistics which render potentially useful data arbitrary.

The third and final problem stems from the way in which research is discussed rather than the way in which it is conducted. As a particularly heinous crime, it is understandable that trafficking in persons conjures sometimes emotive and, subsequently, irrational responses from advocates. However, allowing rising levels of emotions to guide debate and policy intervention is counter productive to meaningful discussion, criticism, and the development of new ideas. Many arguments, and indeed many statistics, relating to trafficking in persons appear to be driven by the mandate and ideology of the source rather than by facts, systematic research, and objective assessments (Lindquist 2013).

This article examines these three research problems in the Australian context, mindful of the fact that trafficking in persons is a crime that occurs on a global scale. The paper presents and contextualises the difficulties of measuring trafficking in persons in Australia by drawing on other, international analyses and debates with the aim to rethink the current approaches used to document, calculate, and guess the extent of trafficking in persons in Australia, and to develop new and more meaningful approaches to this issue.

To achieve this goal, this article adopts a methodology pioneered by Aronowitz (2010), whose research concepts and frameworks are adaptable to the Australian situation. In particular, her work on 'Overcoming the Challenges to Accurately Measuring the Phenomenon of Human Trafficking' examines the many challenges involved in measuring trafficking in persons and offers guidance in identifying the dark figure and the number of presumed victims of this crime.

The ambitious goals of this article are hampered by the fact that quantitative information about trafficking in 
persons in Australia is very limited and that much of the available data lacks the consistency and particularity to allow meaningful conclusions to be drawn and to provide accurate estimates about the true level of trafficking in persons in this country. A further complication stems from the fact that much of the available information, reported cases and government reports in particular, only relate to trafficking in adult women for the purpose of exploitation in Australia's sex industry. The many other forms of trafficking in persons, ranging from labour trafficking to domestic servitude, trafficking in children, to trafficking in persons for the purpose of organ removal, are not similarly documented and there is next to no data available on the phenomena. This distorts this article's ability to explore the full spectrum of trafficking in persons in Australia.

It should be stressed, however, that developing definitive and conclusive figures are not the principal purpose of this article. While approaches to quantifying the problem are offered, they are accompanied with the proviso that trafficking in persons is a deeply nuanced issue impervious to comprehension under any single paradigm.

\section{OFFICIAL DATA}

\section{A. Early Developments}

Until the late 1990s, trafficking in persons-a term not commonly used at that time-was conceptualised as an immigration issue in Australia. Victims of trafficking in persons were primarily seen as 'unlawful non-citizens' and removed from Australia for failing to hold valid visas, as required by the Migration Act 1958 (Cth), Australia's principal immigration statute (Steele 2007). In the absence of specific laws and policies on trafficking, there was also no data on the extent of the problem.

The Australian Government first acknowledged that 'sex-trafficking to and from Australia is part of a large and increasing international trade' at the time specific offences for slavery, sexual servitude, and deceptive recruiting were incorporated into federal criminal law with the Criminal Code Amendment (Slavery and Sexual Servitude) Act 1999 (Cth) (Commonwealth Parliamentary Debates 1999). The introduction of these offences-which were not used in criminal proceedings for several years-were, however, not accompanied by any formalised or coordinated government strategy to combat trafficking in persons, or by any attempt to measure the scale of the problem.
In 2003, the Australian Government's finally undertook more concrete steps to grasp and tackle the problem of trafficking in persons (Australian National Audit Office 2009). The Parliamentary Joint Committee on the Australian Crime Commission launched a first Inquiry into the trafficking of women for sexual servitude in June 2003, and presented its final report a year later. A cornerstone of this inquiry was the acknowledgement of the lack of accurate data, which proved to be a running theme throughout other performance reports in later years (Parliamentary Joint Committee on the Australian Crime Commission 2004; Australian National Audit Office 2009). Accordingly, the Committee's recommendations were in large part grounded by a desire to better understand the level of trafficking in persons in Australia (Parliamentary Joint Committee on the Australian Crime Commission 2004). Official submissions to the inquiry, however, were unwilling to speculate about the actual size of the problem. Then Acting Australian Federal Police (AFP) Deputy Commissioner John Lawler, for instance, remarked that (Quoted in O'Brien, Hayes and Carpenter 2013:85):

The AFP would prefer that the figures that we present to the committee are sustainable figures based on evidence and solid information. We have solid, sustainable evidence and information to support 14 victims that have come to notice for slavery and sexual servitude.

Similarly, the then Sex Discrimination Commissioner for the Human Rights and Equal Opportunities Commission, Sally Moyle, submitted that most instances of trafficking in persons in Australia involve trafficking in women for the purpose of sexual exploitation, but she was not able provide numbers documenting the extent of the problem (O'Brien et al. 2013).

Whilst the Inquiry into the trafficking of women for sexual servitude was still underway, on 13 October 2003, the then Minister for Justice and Customs, Senator Chris Ellison (2003), announced a set of measures to combat trafficking in persons (Segrave 2005). This announcement was followed by the development of an Action Plan to Eradicate Trafficking in Persons which was published in early 2004 (Australia. Attorney-General's Dept.). This 16-page Action Plan articulates four central elements that guide Australia's policy response to trafficking in persons to this day: prevention, detection and investigation, 


\begin{tabular}{|c|c|c|c|}
\hline \multirow[t]{2}{*}{ Financial year } & \multirow{2}{*}{$\begin{array}{l}\text { New referrals for assessment during the } \\
\qquad \text { period }^{b}\end{array}$} & \multicolumn{2}{|c|}{ Total number } \\
\hline & & Since Jan 2004 & Since 1999 \\
\hline $2002-03$ & 20 & & 32 \\
\hline 2003-04 & not available & & 79 \\
\hline 2004-05 & 29 & & 105 \\
\hline 2005-06 & 20 & 110 & \\
\hline 2006-07 & 15 & 125 & \\
\hline $2007-08$ & 17 & 150 & \\
\hline 2008-09 & not available & not available & \\
\hline $2009-10$ & 38 & $270+$ & \\
\hline $2010-11$ & 35 & 305 & \\
\hline 2011-12 & 41 & 346 & \\
\hline 2012-13 & 52 & 398 & \\
\hline
\end{tabular}

Figure 1: Trafficking in person's investigations and assessments, 1 July 2002-30 June 2013. ${ }^{a}$

${ }^{a}$ AFP 2004: 37; AFP 2005: 32; AFP 2011: 50; AFP 2012: 53; AFP 2013: 71; Anti-People Trafficking Interdepartmental Committee 2009: 19.

${ }^{\mathrm{b}}$ Note that some investigations and assessments remain active across one or more reporting periods.

criminal prosecution; and victim support and rehabilitation. The Action Plan also acknowledges Australia's obligations under the United Nations Protocol to Prevent, Suppress, and Punish Trafficking in Persons Protocol, especially Women and Children, which Australia signed on 11 December 2002. To that end, the Action Plan specifically states that Australia will comply with its obligations under the Protocol, inter alia, by monitoring the extent of people trafficking-the term used by federal agencies to refer to trafficking in persons in Australia.

\section{B. Investigations}

Each year, the AFP releases information about the number of trafficking-related investigations and assessments. This information is supplemented by reports of the Australian Government's Anti-People Trafficking Interdepartmental Committee that contain some basic figures about police investigations and assessments relating to trafficking conducted during these periods.

The information displayed in Figure 1 above shows that between 15 and 52 new allegations of trafficking in persons are investigated by Australian authorities each financial year. In the 2012-13 financial year, the AFP received 52 referrals relating to trafficking in persons for assessment, with 29 of those leading to investigations (Australian Federal Police 2013).

\section{Prosecutions}

According to information provided by the Commonwealth Director of Public Prosecutions (CDPP), 17 persons have been convicted for trafficking-related offences since Divisions 270 and 271 of the Criminal Code (Cth) first came into operation. Ten of these defendants were convicted for slavery offences, four of sexual servitude offences, and two for trafficking in persons. As on 30 June 2013, six trafficking matters were before Australian courts. One matter was at sentencing stage, and one at appeal stage (Commonwealth Director of Public Prosecutions 2013). More recent data was not available at the time of writing.

\section{Victims Receiving Government Support}

According to official figures, approximately 200 victims of trafficking in persons have come to the attention of Australian authorities since record keeping started in January 2004. This estimate is based on figures relating to AFP investigations and the number of persons who have obtained specific government support available to trafficked persons in Australia. By 30 June 2012, a total of 193 persons, including 174 women and 19 men, had been referred to the Australian Government's 'Support for Trafficked People Program' since the program's inception in 2004 (AntiPeople Trafficking Interdepartmental Committee 2012). These figures also show that the great majority of 
known victims of trafficking in persons in Australia are women. Trafficking involving male victims or children is very rare by comparison.

The number of victims identified in any one year, and those entering the government support program, fluctuates considerably, as is shown in Figure 2 below. For example, in the 2012-13 financial year, 21 new clients, were referred to the Support for Trafficked People Program, compared to nine in the 2011-12 financial year. A total of 83 persons received support under this program in 2012-13, compared to 77 in the previous financial year. It needs to be noted in this context that a victim may receive support over more than one financial year which may slightly distort these figures. More recent data was not available at the time of writing.

Prior to the inception of the Support for Trafficked People Program, 20 victims has been identified by the AFP in the 2003-04 financial year; 40 were identified in 2004-05 (Australian Federal Police 2005).

\section{E. Initial Observations}

While the official figures relating to investigations and prosecutions of traffickers and the referral of victims of trafficking in persons do not capture the full extent of this crime, the combination of this data gives some insight into the way this phenomenon unfolds in Australia's criminal justice process, moving from initial detection to further investigation, victim referral, on to prosecution and, in some cases, conviction. Seen in combination, as displayed in Figure $\mathbf{3}$ below, it becomes evident how few cases proceed to trial stage and how small the number of 'confirmed' convicted traffickers is.

Figure 3 also demonstrates that, seen in isolation, the various types of official data provide a very different picture of the level of trafficking in persons in Australia. Reliance on the number of convictions alone, for instance, will lead to the conclusion that trafficking in persons is indeed a very rare occurrence. This conclusion is, however, misleading, as the small number of persons convicted may be more reflective of the practical and evidentiary difficulties of obtaining a conviction rather than of the true dimension of this crime.

This is not an issue that is unique to Australia, but one that has been identified by Aronowitz (2010:502) as one the greatest challenges for research in this field:

Even large numbers of arrests often result in only small numbers of convictions. True progress will only be made when cases investigated result in arrests, are brought to the courts and result in conviction and imprisonment of traffickers. In order to gauge the progress a country is making in this area, it is important to link arrest data with court filing data/prosecutions, with actual convictions and sentences handed down.

The available data from Australia is, however, too incomplete to draw these links, making it near

\begin{tabular}{|c|c|c|c|c|c|c|}
\hline Financial Year & $\begin{array}{l}\text { Clients at the } \\
\text { start of the } \\
\text { financial year }\end{array}$ & New Clients & Total Clients & $\begin{array}{l}\text { New Clients } \\
\text { Leaving }\end{array}$ & $\begin{array}{l}\text { Prior Clients } \\
\text { Leaving }\end{array}$ & $\begin{array}{l}\text { Clients at the } \\
\text { end of the } \\
\text { financial year }\end{array}$ \\
\hline 2005-06 & not available & not available & 41 & not available & not available & not available \\
\hline $2006-07$ & not available & not available & 48 & not available & not available & not available \\
\hline 2007-08 & not available & not available & 60 & not available & not available & not available \\
\hline 2008-09 & not available & not available & 59 & not available & not available & 41 \\
\hline 2009-10 & 41 & 24 & 65 & 10 & 4 & 51 \\
\hline 2010-11 & 51 & 29 & 80 & 11 & 1 & 68 \\
\hline 2011-12 & 68 & 9 & 77 & 5 & 10 & 62 \\
\hline 2012-13 & 62 & 21 & 83 & \multicolumn{2}{|c|}{29} & 54 \\
\hline $\begin{array}{c}1 \text { July-31 Dec } \\
2013\end{array}$ & 54 & 11 & 65 & \multicolumn{2}{|c|}{7} & $\begin{array}{c}58 \text { (31 Dec } \\
2013\end{array}$ \\
\hline
\end{tabular}

Figure 2: Number of clients in and referred to the Support for Trafficked People Program, 1 July $2005-31$ December 2013 ${ }^{a}$

${ }^{a}$ Anti-People Trafficking Interdepartmental Committee 2012: 33; Anti-People Trafficking Interdepartmental Committee 2011: 323; Australia. Attorney-General's Dept. 2012: 4; Australia. Attorney-General's Dept. 2013: 4; Australia. Attorney-General's Dept. 2013: 4. 


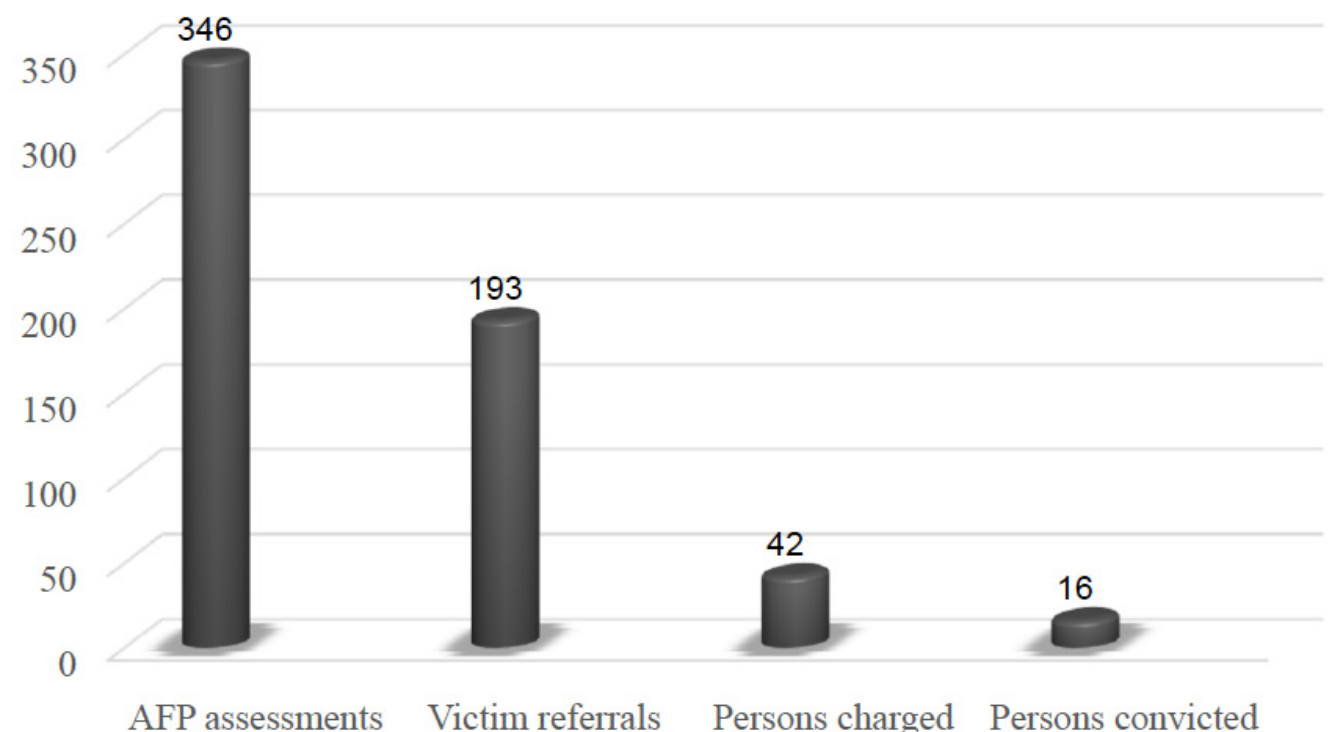

Figure 3: Official data relating to trafficking in persons, 1 July 2004-30 June $2012^{a}$.

${ }^{a}$ Anti-People Trafficking Interdepartmental Committee 2012: 22, 32; AFP 2012: 3; Commonwealth Director of Public Prosecutions 2012: 72. Adapted from Putt 2007: 3.

impossible to document the number of reported trafficking cases, assess the effectiveness of the criminal justice system, and identify the obstacles encountered by police and prosecutors. Conviction and prosecution rates are thus not reliable indicators of the country's trafficking problem (Aromaa 2008).

It is for this reason that many sources prefer to measure the scale of trafficking in persons by reference to the number of identified victims, rather than the number of arrests, prosecutions, and convictions of perpetrators. This may also be a factor contributing to the prevalence of victim-centred conceptualisations and analyses of trafficking in persons generally (Weitzer 2013).

\section{UNOFFICIAL FIGURES}

In addition to official data released by various government agencies, several Australian NGOs have released figures relating to the number of victims of trafficking in persons. Among these NGOs, there is disagreement about the definition of trafficking in persons and thus about the number of victims. There is also a great discrepancy between the number of victims identified and assisted by authorities, and the magnitude of the problem claimed by some NGOs. It is also noteworthy that the figures released by NGOs in Australia focus exclusively on trafficking for the purpose of commercial sexual exploitation and, unlike official data, thus do not capture trafficking in persons in all its forms.

\section{A. Project Respect}

One of the principal advocacy groups in the field of trafficking in persons is Project Respect, a communitybased organisation located in Melbourne, Victoria, that supports women in the sex industry, which includes work with women trafficked into Australia (Anti-People Trafficking Interdepartmental Committee 2011; Australian Government Anti-Human Trafficking Community Resource 2011). Project Respect also receives government funding to provide victim support services, including shelter, peer support activities, case management, counselling, and education (Schloenhardt and Hunt 2012).

In a report first published in 2004, Project Respect claims to have identified over 300 victims of trafficking during a study conducted over a six-week period in early 2004 . These victims are said to relate to 60 cases of trafficking which occurred sometime between 1997 and 2003 , with some cases involving as many as 89 victims from a diverse range of nationalities (Project Respect 2004). Project Respect (2008) suggests that this study 'amply supports' that

around 1,000 women are trafficked in Australia each year and under contract at any one time and still paying off a debt. Realistically, the number could be far greater as we do not know how many women are still in Australia but have left the situation of exploitation, or how many 
women are trafficked for other purposes such as marriage and labour exploitation.

Project Respect further submits that the suggestion of 1,000 victims of trafficking in Australia may be conservative and that a true figure of 2,000 victims 'would not be surprising' (Quoted in O'Brien et al. 2013). The figures published by Project Respect have been used in multiple publications and presentations made by the NGO, and have gained a life of their own after frequent repetition in the media and in other reports (O'Brien and Wynhausen 2003; Lyall 2003; Shaw 2003). It is, however, not possible to independently identify these cases or otherwise validate this information. Other official information or academic research also does not support these figures.

In 2008, the author of the 2004 report and former director of Project Respect, Maltzahn (2008:60), shed further light into the research conducted and, whilst defending the published figures, cast doubt about the methodology and research findings:

In only six weeks of research in early 2004 we documented 300 cases in Australia, the great bulk trafficking for prostitution. This research was clearly partial. We weren't able, for example, to travel to Perth or Adelaide to investigate in more detail stories we had heard of trafficking there. The work was done quickly with few resources, based on interviews with trafficked women themselves, with other people connected to the sex industry, and with NGOs and unions. What it showed, however, was that even a fairly cursory exploration found far too many victims. It reinforced our belief that [...] up to 1000 women could be being trafficked to Australia yearly.

\section{B. Scarlett Alliance}

In 1994, working in conjunction with other advocacy groups, the Scarlet Alliance, an Australian sex workers association, conducted research and used advertising across Australia's sex industry that resulted in an estimate that between 300 and 400 women enter Australia each year intending to perform sex workunder (Brocket and Murray 1994). These numbers were recounted in the group's submission to the Inquiry into the trafficking of women for sexual servitude in 2004, where the Scarlett Alliance noted that among these migrant sex workers, only 10 instances could be identified that involved deceptive recruitment or exploitation of the sex worker. All other cases were said to involve informed consent by the migrant sex worker and general satisfaction with the living and working conditions they encountered in Australia so as to distinguish them from victims of trafficking (Parliamentary Joint Committee on the Australian Crime Commission 2004).

It is difficult, if not impossible, to recapture the calculations made and conclusions drawn in the Scarlett Alliance reports, which appear to rely on selfidentification of victims of trafficking, which is notoriously rare and an unreliable method to measure trafficking in persons (Parliamentary Joint Committee on the Australian Crime Commission 2004; Carrington and Hearn 2003). International and Australian law also do not define victims of trafficking by relying on selfidentification. The estimate made by Scarlett Alliance also lacks accuracy as the research did not involve persons working in unlicensed brothels or engaging in other forms of illegal prostitution (Schloenhardt et al. 2009).

\section{Critique and Observations}

Just as government figures are often criticised for underestimating the level of trafficking in persons in Australia, estimates made by NGOs face criticism for exaggerating the true scale of the problem. A parliamentary briefing paper published in 2003, for instance, expressed concerns about the methods used by NGOs to estimate the number of persons trafficked to Australia, stating that '[s]ome of these methods may inflate the extent of the problem' (Carrington and Hearn 2003:6).

Commenting on the available data at the time, in her submission to the Inquiry into the trafficking of women for sexual servitude, Gallagher (Quoted in Parliamentary Joint Committee on the Australian Crime Commission 2004:20) remarked that:

Much of the current information on trafficking is still anecdotal. It is typically presented in the form of non-statistical data and indirect indicators derived from small-scale surveys and single examples presented as case studies [...]. Where statistics on trafficking cases do exist, their value has been seriously undermined by the lack of a consistent definition of 
trafficking and the absence of uniform collection procedures. Rather than acknowledging or confronting these inadequacies, much contemporary trafficking research unquestioningly accepts and promulgates unverified data.

The problems identified by Gallagher persist today and characterise much of the available research on trafficking in person, not just in Australia (Snajdr 2013).

There is some room for speculation about whether claims made by NGOs pertaining to the high number of victims and about epidemic proportions of trafficking in persons are based on inadequate research, on 'naively, simply reiterating others' assertions', or whether they are the result of ideological motivations. In this context, Weitzer (2012:1348) remarks that '[h]igher numbers are designed to alarm the public and convince governments to commit greater resources to fighting prostitution, to fund rescue operations, and to enhance penalties against traffickers and clients.' The inflated figures may also serve activists in strengthening their own mandate and in their fundraising activities.

Sensationalist claims about the level of trafficking in persons are commonplace and frequently perpetuated by media reporting that inflate available figures rather than conducting journalistic investigations. In 2012, for instance, various Australian media outlets reported that a qualitative study had claimed that 2,000 victims of trafficking in persons could be found within Australia each year (Kapernick 2012; Donovan 2012). Hepworth (email communicaton, 2014), one of the authors of this study, however, provided a far more conservative assessment of the number of trafficked persons than the number reported in the media:

Our research has always maintained that it is largely impossible to establish with certainty the number of people trafficked anywhere. This point was made clear to the media, and in a brief comment also made it clear that there could be as many as between 1,000-2,000, but we just don't know. Unfortunately, the media grossly sensationalised our study, focused solely on numbers and only on 2,000. We were not only incorrectly quoted in relation to the context of what we said, but also, the media distorted the study content, the study aim, and its actual findings. The study was purely qualitative not [quantitative] research. We were extremely disappointed by the handling of this topic by the media and informed them as such.

Based on the available data it is perhaps fair to conclude that trafficking in persons does not appear to occur on a very large scale in Australia and that ' $[t]$ rafficking is generally not as significant a problem as in other countries' (Pearson 2007:29). To that end, the Australian Government (Australian Crime Commission 2011:92) also stresses that '[o]pportunities to traffic people into Australia are limited because of [...] strong migration controls and geographic isolation.' Government sources have, however, also been criticised (Carrington and Hearn 2003:6) for their 'reliance on the actual number of complaints [which] significantly understates the problem'. The true figure is thus likely to be found somewhere between the official numbers reported by Government agencies and those published by NGOs (Parliamentary Joint Committee on the Australian Crime Commission 2004). More accurate estimates, which also take into account the dark figure of this crime, have yet to be made in Australia.

\section{ROOM FOR MISTAKE: DARK FIGURES}

As with other types of crime, officially reported figures relating to trafficking in persons are widely believed to 'reflect only the tip of the iceberg' (Aronowitz 2009:20). That is to say that a significant degree of difference exists between the number of crimes brought to the attention of authorities and the number of crimes that never come to light. The latter is generally referred to as the dark figure of crime (Skogan 1977). In the context of trafficking, Coleman and Moynihan (1996:3) note that:

[T]he particularly elusive nature of trafficking in persons seems to logically result in the existence of a dark figure of indeterminate size and consisting of not simply an unknown score but also unknown features of perpetration not encountered within case law. Remaining mindful of this distinction allows for analysis aware of the shortcomings associated with solely quantitative research which, despite its misgivings, is ultimately beholden to what can be derived from qualitative data. 


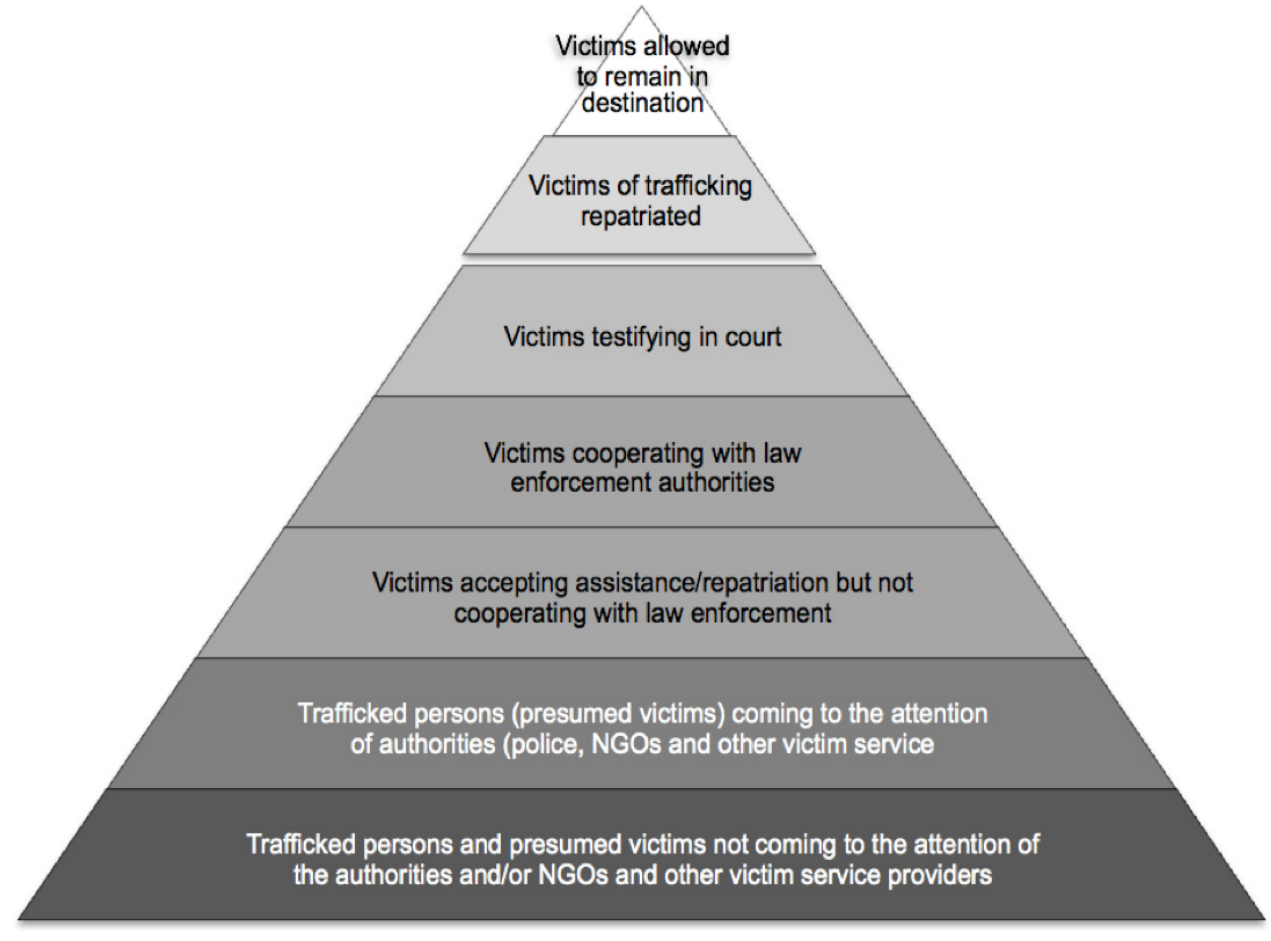

Figure 4: Presumed and Trafficked Persons: Identification and Outcome ${ }^{a}$.

${ }^{\mathrm{a}}$ Taken from Aronowitz 2010:496.

A major problem with the quantitative aspect of the dark figure is its immunity to the application of linear, mathematical modelling. While some analyses may endeavour to present this area of research as progressively revealing layers of the hidden numbers, more critical approaches suggest that such efforts merely re-emphasise different aspects of a problem of indeterminate size (Coleman and Moynihan 1996).

\section{A. Trafficked Persons and Presumed Victims}

Of the sources that speculate about the 'true' scale of trafficking in persons, few offer methods to examine the crime's dark figure (Albanese 2007; Newton, Mulcahy and Martin 2008). Among these, the work of Aronowitz (2010) stands out as one of the most plausible and sustainable models. In particular, her article entitled 'Overcoming the Challenges to Accurately Measuring the Phenomenon of Human Trafficking' examines the many challenges involved in measuring trafficking in persons and offers guidance in identifying the dark figure and the number of presumed victims of this crime. The methodology developed in her article also lends itself to adaptation in a variety of settings and jurisdictions, including Australia.

Aronowitz's approach to mapping the dark figure of trafficking in persons involves qualitative labels of victims ordered by the level of cooperation they afforded authorities. As a rule, these categories correspond to a pyramid system in which the fewest victims appear in the highest order as providing the most cooperation while the most victims appear in the lowest order for having been the least cooperative. The utility of the model arises from the placement of the dark figure categories at the pyramid's base. The model then suggests that the unknown categories must be of a higher value than those in the tiers above. Aronowitz's pyramid model thus provides a useful method to examine the relationship between official figures and dark figures of trafficking in persons.

The top five tiers of the pyramid model shown in Figure $\mathbf{4}$ above represent known quantities of victims. These tiers are not mutually exclusively so that victims in a higher tier may also be included in a lower tier. The bottom two tiers referring to 'trafficked persons and presumed victims' constitute the category commonly referred to as the dark figure of victims of trafficking in persons.

The pyramid's qualitative description of victim categories allows for quantitative information to be added where such information is available. Using the information available on the number of victims of trafficking in Australia, the following sections explore Aronowitz's modelling in the Australian context. Information and data pertaining to the tiers established 
by Aronowitz can be found in reports published by the Australian Government's Anti-People Trafficking Interdepartmental Committee that has published four reports entitled Trafficking in Persons: The Australian Government's Response since 2009. The fifth report for the period 1 July 2012 to 30 June 2013 had not been published at the time this article was taking shape. In addition, six-monthly Performance Management Reports are published by the AttorneyGeneral's Department, most recently for the period 1 July-31 December 2013. These sources contain information about the number of investigations led by the AFP and, as mentioned earlier, the number of victims identified by Australian authorities and referred to the Government's 'Support for Trafficked Persons Program'.

\section{B. Visa Classes for Victims of Trafficking in Persons in Australia}

Also included in the above-mentioned government reports are statistics about the visas issued to persons who have been identified as victims of trafficking in persons and who required a visa to legitimise their continuing stay in Australia. The three-formerly fourclasses of visas available to victims of trafficking correspond to some degree with the classification developed by Aronowitz. The way in which the Australian visa regime operates allows conclusions to be drawn about the extent and quality of cooperation between the victim and Australian authorities based on the type of visa granted. No such conclusions are, however, possible for victims of trafficking in persons who are Australian citizens, permanent residents, or who are otherwise lawfully in Australia and do not require a new or a different visa to remain in the country. It also does not include victims who depart, voluntarily or involuntarily, from Australia.

When first introduced in 2004, Australia's so-called 'People Trafficking Visa Framework' included four visa types: the Bridging $F$ visa, the pre-existing Criminal Justice Stay visa, the Witness Protection (Trafficking) (Temporary) visa, and the Witness Protection (Trafficking) (Permanent) visa. The Witness Protection (Trafficking) (Temporary) visa was removed by amendments made in 2009.

The three visas currently available to victims of trafficking in persons broadly reflect stages of the investigation and prosecution process. The Bridging $\mathrm{F}$ visa allows any suspected victims of trafficking to stay in Australia for a short-term period to recover, access support services and assess future options: Class WF, subclass 060, under Migration Regulations 1994 (Cth) sch 1 item 1306. Should the victim opt to stay in Australia to participate in a criminal investigation or prosecution, he or she may be issued a Criminal Justice Stay visa for the duration of the investigation or prosecution: Migration Act 1958 (Cth) pt 2 div 4 sub-div (D). A Witness Protection (Trafficking) (Permanent) visa may be granted during or following the conclusion of a prosecution, or where there is a decision not to prosecute, if the victim, having participated in the process, requires permanent protection because returning home would be dangerous as a result of this participation: Class DH, subclass 852, Migration Regulations 1994 (Cth) reg 2.07AK.

Figure 5 below displays the number of visas granted under the People Trafficking Visa Framework between 1 July 2003 and 31 December 2013. It has to be noted that the number of visas cited includes those granted to both suspected victims of trafficking and their immediate family members, and that in some cases the number will include the grant of the same visa type to a person on more than one occasion (this may be the case for Bridging $F$ visas and Criminal Justice Stay visas).

When combined with the data relating to victims referred to the Government's support program, shown in Figure $\mathbf{2}$ above, the numbers shown in Figure $\mathbf{5}$ correspond, by and large, with the tiers established by Aronowitz.

\section{Trafficked Victims and Presumed Victims in Australia}

In order to correctly display the available data from Australia, the tiers established by Aronowitz have been modified to the following four categories:

- 'candidates for repatriation among known victims' replaces 'victims of trafficking repatriated' and is now the highest tier;

- 'victims allowed to remain in Australia' replaces 'victims allowed to remain in destination' and is now the second tier;

- vvictims granted Criminal Justice Stay Visas while cooperating in prosecutions and investigation' replaces and combines the categories of 'victims cooperating with law enforcement authorities' and 'victims testifying in court'; 


\begin{tabular}{|c|c|c|c|c|}
\hline Financial Year & Bridging $F$ visa & $\begin{array}{c}\text { Criminal Justice Stay } \\
\text { visa }\end{array}$ & $\begin{array}{c}\text { Witness Protection } \\
\text { (Trafficking) } \\
\text { (Temporary visa }\end{array}$ & $\begin{array}{c}\text { Witness Protection } \\
\text { (Trafficking) } \\
\text { (Permanent) visa }\end{array}$ \\
\hline 2003-04 & 11 & 5 & 0 & 0 \\
\hline 2004-05 & 31 & 23 & 0 & 0 \\
\hline 2005-06 & 11 & 8 & 0 & 0 \\
\hline $2006-07$ & 16 & 18 & 4 & 0 \\
\hline 2007-08 & 34 & 18 & 13 & 0 \\
\hline 2008-09 & 39 & 30 & 0 & 5 \\
\hline $2009-10$ & 33 & 23 & not offered & 21 \\
\hline $2010-11$ & 24 & 29 & not offered & 28 \\
\hline 2011-12 & 12 & 15 & not offered & 16 \\
\hline $2012-13$ & 14 & 17 & not offered & 12 \\
\hline 1 July-31 December 2013 & 5 & 11 & not offered & 2 \\
\hline
\end{tabular}

Figure 5: Visas granted under the People Trafficking Visa Framework, 1 July 2003-31 December 2013 .

${ }^{a}$ Anti-People Trafficking Interdepartmental Committee 2012: 29; Anti-People Trafficking Interdepartmental Committee 2011: 30; Australia. Attorney-General's Dept. 2012: 4; Australia. Attorney-General's Dept. 2013: 4; Australia. Attorney-General's Dept. 2013 (1 July-31 December 2013): 4.

- 'victims and suspected victims accepting government assistance' replaces 'victims accepting assistance/repatriation but not cooperating with law enforcement'.

Placing the available data into these four categories results in a pyramid model, shown in Figure 6 below, identical to that developed by Aronowitz. The calculation for each category is explained in the following sections. What is thus far missing is the number of 'presumed victims and trafficked persons' in the bottom two tiers, i.e. the dark figure of victims of trafficking in persons.

\section{Candidates for Repatriation among known Victims}

This category, placed at the top of the pyramid, is constituted by the number of known victims of trafficking in persons that have left the government support program during the sample period. The available data pertaining to this category and the calculation of the total number of clients leaving the program are shown in Figure 7 above. An unavoidable
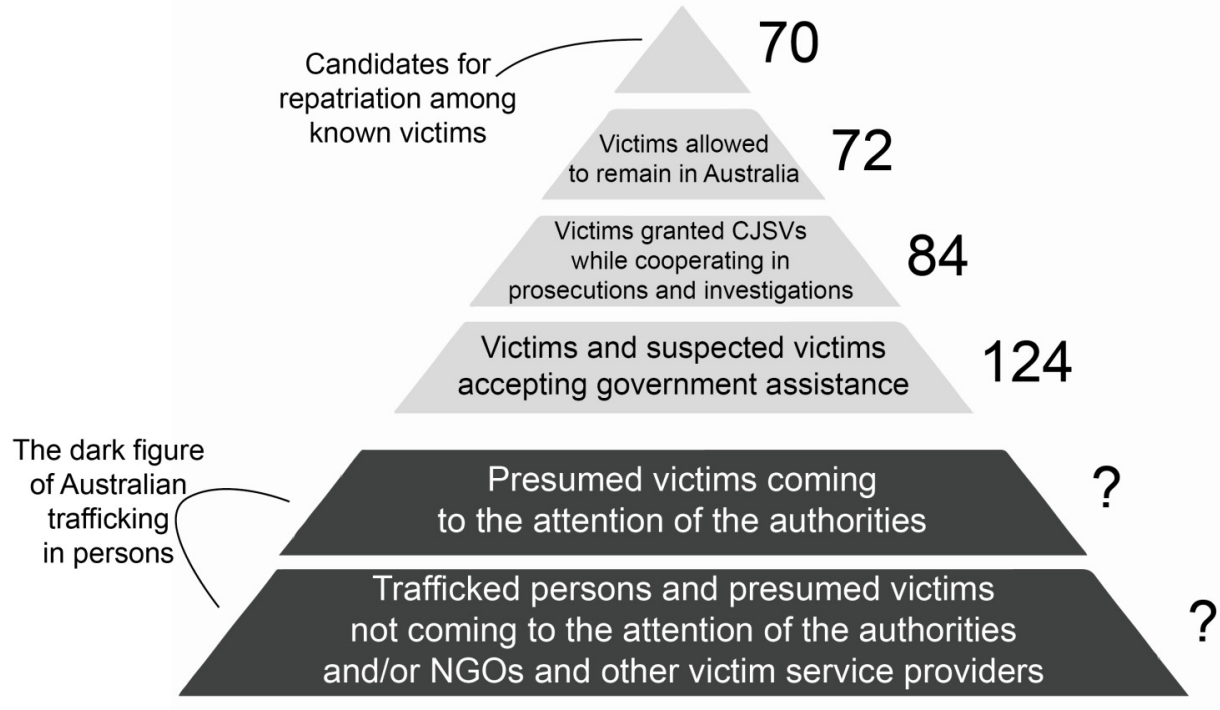

Figure 6: Trafficked Persons: Identification and Outcome, 1 July 2009-31 June 2013 .

${ }^{\mathrm{a}}$ Based in part on Aronowitz 2010: 496. Data applied from Anti-People Trafficking Interdepartmental Committee. 2012: 29; Australia. Attorney-General's Dept. 2012 (1 July-31 December): 4; Australia. Attorney-General's Dept. 2013 (1 January-30 June): 4; Australia. Attorney-General's Dept. 2013 (1 July-31 December 2013): 4. 


\begin{tabular}{|c|c|c|c|c|c|c|}
\hline $\begin{array}{l}\text { Financial } \\
\text { Year }\end{array}$ & $\begin{array}{c}\text { Clients at the start of } \\
\text { the year }\end{array}$ & New Clients & Total Clients & $\begin{array}{l}\text { New Clients } \\
\text { Leaving }\end{array}$ & $\begin{array}{l}\text { Prior Clients } \\
\text { Leaving }\end{array}$ & $\begin{array}{l}\text { Clients at the } \\
\text { end of the year }\end{array}$ \\
\hline 2008-09 & not available & not available & 59 & not available & not available & 41 \\
\hline 2009-10 & 41 & 24 & 65 & 10 & 4 & 51 \\
\hline 2010-11 & 51 & 29 & 80 & 11 & 1 & 68 \\
\hline 2011-12 & 68 & 9 & 77 & 5 & 10 & 62 \\
\hline $2012-13$ & 32 & 21 & 83 & \multicolumn{2}{|c|}{29} & 54 \\
\hline & & & & \multicolumn{2}{|c|}{ Clients leaving the program: } & \\
\hline
\end{tabular}

Figure 7: Calculating repatriation candidates, 1 July 2008-31 June $2013^{\mathrm{a}}$.

${ }^{a}$ Anti-People Trafficking Interdepartmental Committee 2010: 12; Anti-People Trafficking Interdepartmental Committee 2011: 32; Anti-People Trafficking Interdepartmental Committee 2012: 31; Australia, Attorney-General's Dept. 2012 (1 July-31 December): 4; Australia. Attorney-General's Dept. 2013 (1 January-30 June 2013): 4; Australia. Attorney-General's Dept. 2013 (1 July-31 December): 4.

weakness present in this calculation is that the result may include some victims granted a permanent resident visa and exclude others that do not enter the Support for Trafficked People Program. While it is difficult to assess how close this calculation is to the actual number of repatriated victims, it seems likely that the difference between this category and that proposed in Aronowitz's original design would not be great enough to alter the ordering of the tiers.

\section{Victims Allowed to Remain in Australia}

The second category refers to the number of victims of trafficking in persons known to have been granted permanent residence in Australia after they cooperated with law enforcement during the sample period. Given that there does not appear to be any requirement that recipients of this visa remain in the government program, there may be some overlap between the number calculated in Figure $\mathbf{8}$ and the number calculated in Figure 7. Regardless, this overlap is, in all likelihood, not complete, thus rendering the second tier larger than the first.

\section{Victims Granted Criminal Justice Stay Visas while Cooperating in Prosecutions and Investigations}

The third category combines Aronowitz's categories of 'victims testifying in court' with those 'cooperating with investigations'. In the Australian context, these two tiers need to be combined and cannot be differentiated because of a lack of specificity within the visa data. This tier is calculated on the basis of the number of Criminal Justice Stay Visas that were granted during the sample period, see Figure 9 below. There may be some overlap between this category and the 'victims allowed to remain in Australia' category as some individuals may change visa status within the reporting period.

\section{Victims and Suspected Victims Accepting Government Assistance}

The fourth category includes all persons who have obtained assistance under the Australian Government's Support Program, as shown in Figure $\mathbf{1 0}$ below. Here, it is more difficult to provide accurate figures and state with certainty that this category encompasses the

\begin{tabular}{ccccc}
\hline Financial Year & Bridging F visa & $\begin{array}{c}\text { Criminal Justice Stay } \\
\text { visa }\end{array}$ & $\begin{array}{c}\text { Witness Protection } \\
\text { (Trafficking) } \\
\text { (Temporary visa }\end{array}$ & $\begin{array}{c}\text { Witness Protection } \\
\text { (Trafficking) } \\
\text { (Permanent) visa }\end{array}$ \\
\hline $\mathbf{2 0 0 8 - 0 9}$ & 39 & 30 & 0 & 5 \\
\hline $\mathbf{2 0 0 9 - 1 0}$ & 33 & 23 & not offered & 16 \\
\hline $\mathbf{2 0 1 0 - 1 1}$ & 24 & 29 & not offered & 28 \\
\hline $\mathbf{2 0 1 1 - 1 2}$ & 12 & 15 & not offered & 16 \\
\hline $\mathbf{2 0 1 2 - 1 3}$ & 14 & 17 & not offered & 12 \\
\hline
\end{tabular}

Figure 8: Calculating victims allowed to remain in Australia, 1 July 2008-30 June 2013 ${ }^{a}$.

${ }^{a}$ Anti-People Trafficking Interdepartmental Committee 2012: 29; Anti-People Trafficking Interdepartmental Committee 2011: 30; Australia. Attorney-General's Dept. 2012 (1 July-31 December): 4; Australia. Attorney-General's Dept. 2013 (1 January-30 June 2013):4; Australia. Attorney General's Dept. 2013 (1 July-31 December): 4. 


\begin{tabular}{|c|c|c|c|c|c|}
\hline Financial Year & Bridging $F$ visa & $\begin{array}{l}\text { Criminal } \\
\text { Justice Stay } \\
\text { visa }\end{array}$ & & $\begin{array}{c}\text { Witness Protection } \\
\text { (Trafficking) (Temporary } \\
\text { visa }\end{array}$ & $\begin{array}{c}\text { Witness Protection } \\
\text { (Trafficking) (Permanent) } \\
\text { visa }\end{array}$ \\
\hline 2008-09 & 39 & 30 & & 0 & 5 \\
\hline 2009-10 & 33 & 23 & & not offered & 21 \\
\hline 2010-11 & 24 & 29 & \multirow{3}{*}{$\begin{array}{c}\text { Criminal } \\
\text { Justice Stay } \\
\text { visas granted: } \\
84\end{array}$} & not offered & 28 \\
\hline 2011-12 & 12 & 15 & & not offered & 16 \\
\hline 2012-13 & 14 & 17 & & not offered & 12 \\
\hline
\end{tabular}

Figure 9: Calculating victims granted visas for cooperating with law enforcement, 1 July 2008-30 June 2013 ${ }^{\text {. }}$

${ }^{a}$ Anti-People Trafficking Interdepartmental 2012: 29; Anti-People Trafficking Interdepartmental Committee 2011: 30; Australia. Attorney-General's Dept. 2012 (1 July-31 December): 4; Australia. Attorney-General's Dept. 2013 (1 January-30 June): 4 ; Australia. Attorney-General's Dept. 2013 (1 July-31 December 2013): 4.

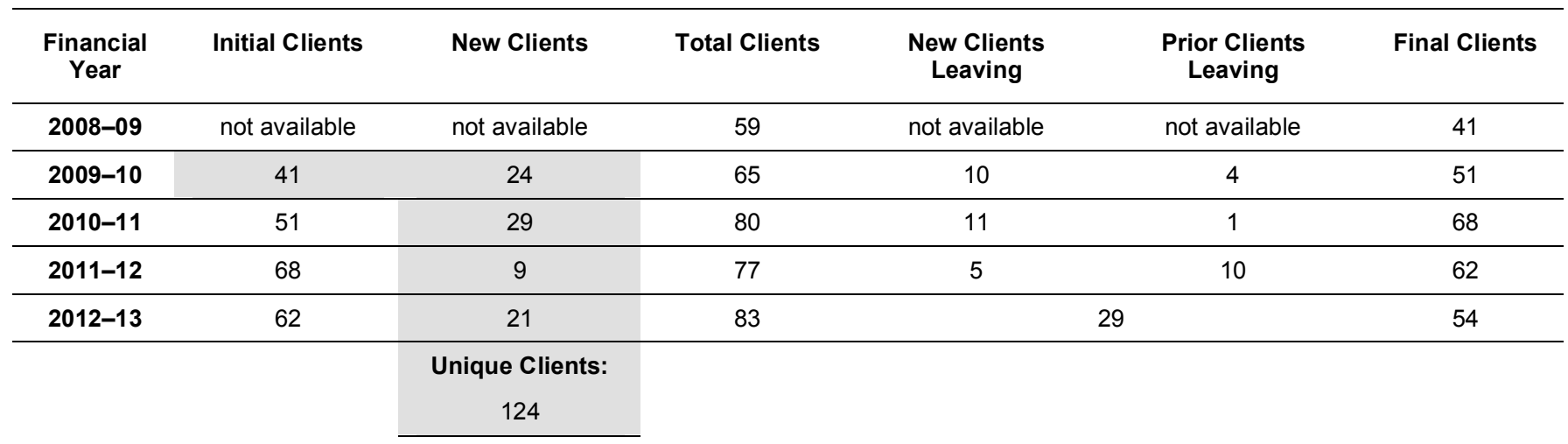

Figure 10: Calculating total unique clients receiving government assistance, 1 July 2008-30 June $2013^{\mathrm{a}}$.

${ }^{a}$ Anti-People Trafficking Interdepartmental Committee 2010:12; Anti-People Trafficking Interdepartmental Committee 2011: 32; Anti-People Trafficking Interdepartmental Committee2012:31; Australia. Attorney-General's Dept. 2012 (1 July-31 December 2012): 4; Australia. Attorney-General's Dept. 2013 (1 January-30 June): 4; Australia. Attorney-General's Dept. 2013 (1 July-31 December): 4.

higher tiers of the pyramid, which are based on the grant of visas. It is conceivable, for instance, that a person may be granted a relevant visa to remain in Australia but does not accept or receive government assistance. There is also space in this fourth category for victims who already hold a valid visa prior to receiving assistance from the Australian Government. The calculation for category four is displayed in Figure 10 above.

\section{Presumed Victims of Trafficking in Persons in Australia}

As mentioned previously, the bottom two categories of the pyramid shown in Figure 6 above represent the dark figure of victims of trafficking in persons. Aronowitz (2010) leaves the term 'presumed victim' used in these two categories undefined and open to interpretation. Nonetheless, her basic concept suggests that a presumed victim shares enough qualities with known cases of trafficking in persons to make them statistically noteworthy but not to such an extent so as to elevate them to the standard of a suspected victim capable of accepting government assistance.

The distinction between identified and presumed victims stems for the willingness (or lack thereof) of an individual to identify herself or himself as a victim of trafficking in persons. To shed further light into the number of presumed victims, Aromaa (2007:19) suggests that:

NGOs may be compiling some kind of working statistics about their clients, visits, and measures taken [...]. Volume estimates are indeed often derived from such sources. [...] It would desirable if NGOs could adopt some shared counting rules, starting with shared definitions that are suitable for their work and can be derived from it [...] the presumed victim is a potentially valuable informer who sometimes may be very knowledgeable, 
sometimes very ignorant. This observation means that we need to define what information an NGO and a victim-focused authority should try to collect as a standard routine.

In the absence of such measures and data collections, the only possible estimate of the number of presumed victims of trafficking in persons in Australia is that this number is greater than 110 during the four year period. Just how much greater this number really is or might be cannot be determined at this point in time and remains the most challenging to uncover. To do so, would require the development of a method to establish the number or percentage of victims of trafficking in persons who come in contact with government agencies or NGOs against those who do not (Di Nicola 2013; Laczo 2007).

\section{Addressing the Shortfalls}

In attempting to estimate the dark figure of victims of trafficking in persons-and thus grasp the true extent of this problem in Australia-two main shortfalls need to be addressed.

The first involves the creation of a mechanism to record indicia and other signs of trafficking in persons. This could, for example, take the form of an operational manual recording all known signs of trafficking in persons, founded upon Australian case experience in order to guide presumed victim reports. To that end, the AFP (website 2013) already publishes a list of 'signs [that] a person may be a victim of trafficking' and a Community Resource (AFP website 2011) which outlines the roles and mandates of government agencies and NGOs working in this field. These resources could be adapted into a standardised document for use by law enforcement agencies, NGOs and advocacy groups, and other individuals and organisations who are likely to come into contact with presumed victims so that they can record relevant signs and indicators, even if the person does not later enter the government support program and/or does not receive a relevant visa. Such a document could also be used in training programs on victim identification. The standardisation of the reporting process may also help reduce the potential for anomalies created by the application of contentious definitions and data collection procedures. It is also critical that the exact methodology employed by this process is publically available in order for its limitations to be evaluated (Kangaspunta 2007), and that the contents of such a document are constantly reviewed and updated to keep pace with new and changing characteristics of trafficking in persons in Australia.

The second reporting mechanism would be the creation of 'a national focal point-a national rapporteur or equivalent mechanism, or independent body-to collect and analyse data', as suggested by Aronowitz (2010:502). In Australia, the Anti-People Trafficking Interdepartmental Committee could exercise this function. This body, comprising representatives from a host of federal agencies, was set up by the Australian Government in March 2003 and produces annual reports on the number of victims receiving government supported and/or granted relevant visas (Schloenhardt and Jolly 2013). Acting as a national focal point, the Committee is in a unique position to collate, analyse, and disseminate information on presumed victims and the dark figure of trafficking in persons in Australia, and develop a methodology to ensure consistency and avoid duplication in the data collection process (Biderman and Reiss 2005).

In combination, these two mechanisms will allow quantitative data to be informed by qualitative sources (Noaks and Wincup 2004). This approach would also have wider use and implications, not just in improving the understanding of the scale of trafficking in persons, but also in informing policy development and law reform in this field. In this context, Larsen and Renshaw (2012:2) have noted that:

Notwithstanding these challenges and the relatively small number of trafficked persons detected in Australia by immigration and law enforcement authorities, much can be learned from the investigation and prosecution of these cases regarding the nature of and trends in trafficking. Sources such as case files, interview transcripts, court transcripts and administrative/operational data can be used to build a picture of the trafficking process from recruitment in the country of origin through to arrival in the destination country, including identifying characteristics of trafficked persons and offenders. Further, information from NGOs provide an important insight into trafficking that is not limited by current legislative or administrative frameworks. Vital qualitative information gathered from these sources can add depth to existing official statistics and data. 


\section{E. Further Observations}

An additional complication in trying to quantify and estimate the extent of trafficking in persons, including the dark figure of this phenomenon, is the fact that the available evidence suggests that the ways in which people are trafficked into Australia is very diverse, that no two cases are the same, and that the manifestations and levels of trafficking in Australia differ quite considerably from the experiences abroad. There are some common denominators that link most of the documented cases to Australia's prostitution industry, including licensed and illegal brothels, and to Australia's main urban centres, especially Sydney and Melbourne. Cases from other parts of Australia, including other capital cities and rural areas, are extremely rare and isolated.

For the most part, the reported cases recount actual and attempted trafficking efforts by amateurs, couples, and loosely connected networks. There is, to this day, no evidence of any involvement of organised crime syndicates and large international trafficking rings in trafficking in persons to Australia (Schloenhardt and Jolly 2013). Offending involving more than a handful of victims also appears to be the exception rather than the rule (Schloenhardt, Beirne and Corsbie 2009; AFP 2004:37; AFP 2006:35-6; AFP 2007:25). The lack of sophisticated trafficking operations among the uncovered trafficking cases in Australia has led different authors to different conclusions about their existence, with some sources suggesting that the more sophisticated and clandestine trafficking cases have not been uncovered, and others suggesting that such cases do not exist (Larsen and Renshaw 2012; Putt 2007; Lazos 2007).

The difficulty of these conclusions is that they present unfalsifiable assumptions that are based on the absence rather than the existence of evidence. This creates a 'Russell's Teapot' fallacy, which is to say that the existing data's inability to disprove the premise of the claim is provided in place of empirical evidence of its own (Landini 2010).

Such claims make it all the more necessary to conduct extensive and systematic victimisation research into the types and numbers of presumed victims of trafficking, which has yet to be undertaken in Australia. The recording and reporting mechanisms outlined before would go some way to displace common myths and assumptions and unmask one more aspect of the dark figure of trafficking in persons in Australia. A separate, methodical victimisation study that examines a chosen population's experience with victimisation in order to estimate the victimisation rate of a larger population, should also follow (Coleman and Moynihan 1996). The limitations of such a study, however, also need to be acknowledged, which include, inter alia, the reluctance of victims to selfidentify and the different levels of awareness of trafficking in persons in different parts of Australia.

\section{CONCLUSION}

This article demonstrates the complexities in gathering complete and accurate data on the scale of trafficking in persons in Australia. No complete and comprehensive collection of such data currently exists, which has not stopped some authors from making wild speculations about how great and widespread Australia's 'trafficking problem' might be. It has also been shown that official figures provided by Australian authorities are far from complete and are likely to be a very poor reflection of the true extent of this phenomenon. Measuring trafficking in persons in Australia remains a great challenge and in the absence of better and more complete data many researchers seem to be doing no more than counting shadows when they attempt to grasp the level of trafficking and estimate the number of victims.

The debate over numbers and levels should, however, not distract from the characteristics of trafficking in persons and the fact that trafficking in persons in Australia does take place, as is evidenced in many reported cases and in-depth research. Relevantly, it must be remembered that it is the quality, not the quantity, of trafficking in persons that elevates the phenomenon to an important criminal justice and human rights challenge. 'Society's concerns about trafficking', remark Bazely and Dottridge (AusAID Southeast Asia Region 2011:15), 'are not because there are "no" known cases per year, but simply because it exists-as a societal abhorrence and an abuse of human rights.'

Nevertheless, statistics on the scale and nature of trafficking in persons are necessary, not only to gain an understanding of the size of the problem, but also because statistics are used to call for and justify the allocation and prioritisation of resources to law enforcement agencies, NGOs, victim support services, and prevention efforts. To focus solely upon the terrible nature of the crime is as misguided as focusing purely upon arbitrary numbers. Engaging with both variables, 
quantity and quality, is required for a complete analysis.

Trafficking in persons in Australia is a uniquely nuanced crime covering a diverse range of criminal activities, victims, perpetrators, and types of exploitation. This is also reflected in the documented case law. This reality is at odds with a homogenous culture of reporting that enables generalisations and anecdotal evidence to form initial conditions, tainting research assumptions in the process. The Australian debate suffers from the ideological posturing of interest groups on the one hand, and an attitude of conservatism from official authorities on the other. While the Australian Government's response to this crime has many admirable and robust features, the failure to explore the dark figure-that is the true extent-of the phenomenon is a grave mistake that hampers public discourse and policy making in this field.

The principal recommendation from this research is thus a call for government-sanctioned estimates of the true number of trafficking cases, perpetrators, and victims in Australia. Such estimates could take the form of a national victimisation study or other surveys that need to be accompanied by efforts to detect and record instances of presumed victimisation at each stage of contact.

These steps should go hand-in-hand with greater cooperation and information exchange between government agencies, NGOs, and academic researchers in this field. The creation of a single, national focal point would also be advisable in this context. Data collection, analysis, and dissemination need to become more transparent and different research methodologies need to be disclosed and tested. Greater efforts should also be made to link data relating to criminal intelligence, to investigations, arrests, prosecutions, and convictions, to provide a more complete picture, avoid double-counting, and enable cases to be followed through the criminal justice process. Such data may also foster greater cooperation and communication between different agencies.

The authors wish to thank the members of the UQ Migrant Smuggling Working Group for their support and friendship at the time this manuscript was taking shape. For further information, visit www.law.uq.edu.au/ humantrafficking.

\section{REFERENCES}

Albanese, Jay. 2007. "A Criminal Network Approach to Understanding \& Measuring Trafficking in Human Beings." Pp. 55-72 in Measuring Human Trafficking - Complexities and Pitfalls, edited by E.U. Savona and S. Stefanizzi. New York: Springer.

Anti-People Trafficking Interdepartmental Committee.2009. Trafficking in Persons: The Australian Government's Response January 2004-April 2009.

Anti-People Trafficking Interdepartmental Committee. 2011. Trafficking in Persons: The Australian Government's Response 1 July 2010-30 June 2011.

Anti-People Trafficking Interdepartmental Committee. 2012. Trafficking in Persons: The Australian Government's Response 1 July 2011 - 30 June 2012.

Anti-People Trafficking Interdepartmental Committee. Trafficking in Persons: The Australian Government's Response 1 May 2009 - 30 June 2010.

Aromaa, Kauko. 2007. "Uniform Definitions for Measuring Trafficking." Pp. 13-27 in Measuring Human Trafficking Complexities and Pitfalls, edited by E.U. Savona and S. Stefanizzi. New York: Springer.

Aronowitz, Alexis A. 2009. Human Trafficking, Human Misery: The Global Trade in Human Beings. Westport, CT: Greenwood Press.

Aronowitz, Alexis A.. 2010."Overcoming the Challenges to Accurately Measuring the Phenomenon of Human Trafficking" International Review of Penal Law 81:493-511.

AusAID Southeast Asia Region. 2011. Asia Regional Trafficking in Persons Project (ARTIP Report). < http://aid.dfat.gov.au/ countries/eastasia/regional/Documents/asia-regionaltrafficking-in-persons-report.pdf > (accessed on 17/08/2014).

Australia. Attorney-General's Dept.2004. Australian Government's Action Plan to Eradicate Trafficking in Persons. Canberra, ACT: Australian Government.

Australia. Attorney-General's Dept. 2010 (1 January-30 June). Australian Government Strategy to Combat Human Trafficking and Slavery Whole-of-Government Performance Management Reporting. Canberra, ACT: Australian Government.

Australia. Attorney-General's Dept. 2010 (1 July-31 December). Australian Government Strategy to Combat Human Trafficking and Slavery Whole-of-Government Performance Management Reporting. Canberra, ACT: Australian Government.

Australia. Attorney-General's Dept. 2011 (1 January-30 June). Australian Government Strategy to Combat Human Trafficking and Slavery Whole-of-Government Performance Management Reporting. Canberra, ACT: Australian Government.

Australia. Attorney-General's Dept. 2011 (1 July-31 December). Australian Government Strategy to Combat Human Trafficking and Slavery Whole-of-Government Performance Management Reporting. Canberra, ACT: Australian Government.

Australia. Attorney-General's Dept. 2012 (1 January-30 June). Australian Government Strategy to Combat Human Trafficking and Slavery Whole-of-Government Performance Management Reporting. Canberra, ACT: Australian Government.

Australia. Attorney-General's Dept. 2012 (1 July-31 December). Australian Government Strategy to Combat Human Trafficking and Slavery Whole-of-Government Performance Management Reporting. Canberra, ACT: Australian Government. 
Australia. Attorney-General's Dept. 2013 (1 January-30 June). Australian Government Strategy to Combat Human Trafficking and Slavery Whole-of-Government Performance Management Reporting. Canberra, ACT: Australian Government.

Australia. Attorney-General's Dept. 2013 (1 July-31 December). Australian Government Strategy to Combat Human Trafficking and Slavery Whole-of-Government Performance Management Reporting. Canberra, ACT: Australian Government.

Australia. Minister for Justice \& Customs, Chris Ellison, Transcript of Doorstep Interview, (Parliament House, Canberra, ACT, 13 October 2003).

Australian Crime Commission. 2011.Organised Crime in Australia 2011. Canberra, ACT: Australian Government.

Australian Federal Police. 2004. Annual Report 2003-04. Canberra, ACT: Australian Government.

Australian Federal Police. 2005. Annual Report 2004-05. Canberra, ACT: Australian Government.

Australian Federal Police. 2006. Annual Report 2005-06. Canberra, ACT: Australian Government.

Australian Federal Police. 2007. Annual Report 2006-07. Canberra, ACT: Australian Government.

Australian Federal Police. 2008. Annual Report 2007-08. Canberra, ACT: Australian Government.

Australian Federal Police. 2009. Annual Report 2008-09. Canberra, ACT: Australian Government.

Australian Federal Police. 2010. Annual Report 2009-10. Canberra, ACT: Australian Government.

Australian Federal Police. 2011. Annual Report 2010-11. Canberra, ACT: Australian Government.

Australian Federal Police. 2011. Anti-Human Trafficking Community Resource<http://www.afp.gov.au/policing/ /media/afp/pdf/a/A nti-HumanTraffickingCommunityResource.ashx $>$ (accessed on 17/08/2014).

Australian Federal Police. 2011.Anti-Human Trafficking Community Resource<http://www.afp.gov.au/policing/ /media/afp/pdf/a/A nti-HumanTraffickingCommunityResource.ashx > (accessed on 17/08/2014).

Australian Federal Police. 2012. Annual Report 2011-12. Canberra, ACT: Australian Government.

Australian Federal Police. 2013. Annual Report 2012-13. Canberra, ACT: Australian Government.

Australian Federal Police. 2013. Human Trafficking<http://www.afp. gov.au/policing/human-trafficking.aspx $>$ (accessed on 17/08/2014).

Australian National Audit Office. 2009. Management of the Australian Government's Action Plan to Eradicate Trafficking in Persons. Canberra, ACT: Australian Government.

Biderman, Albert D., Albert J. Reiss Jr. 2005. "On Exploring the "Dark Figure"” of Crime" Pp. 201-15 in Quantitative Methods in Criminology, edited by S. Bushway and D. Weisburd. Burlington: Ashgate Publishing.

Brockett, Linda and Alison Murray. 1994. "Thai Sex Workers in Sydney." Pp. 191-202 in Sex Work and Sex Workers in Australia, edited by Roberta Perkins. Sydney: UNSW Press.

Carrington, Kerry and Jane Hearn. 2003. "Trafficking and the Sex Industry: From Impunity to Protection." (Parliament of Australia, Current Issues Brief No. 28). Canberra, ACT: Parliament of Australia.

Coleman, Clive and Jenny Moynihan. 1996. Understanding Crime Data: Haunted By the Dark Figure. London: Open University Press.

Commonwealth Director of Public Prosecutions. 2013.Annual Report 2012-13. Canberra, ACT: Australian Government.
Commonwealth Director of Public Prosecutions. 2012.Annual Report 2011-12. Canberra, ACT: Australian Government.

Commonwealth, Parliamentary Debates, House of Representatives, 11 Aug 1999, 8497-8498 (Sharman Stone, Parliamentary Secretary to the Minister for the Environment and Heritage).

Di Nicola, Andrea. "Researching Into Human Trafficking: Issues and Problems." Pp. 49-72 in Human Trafficking, edited by M. Lee. New York: Taylor and Francis.

Donovan, Samantha. 2012. "Study Critical of Support for Trafficked Women," ABC News (online), October $3<$ http://www.abc. net.au/news/2012-10-03/study-critical-of-support-fortrafficked-women/4292686> (accessed on 17/08/2014).

Kangaspunta, Kristiina. 2007. "Collecting Data on Human Trafficking: Availability, Reliability and Comparability of Trafficking Data." Pp. 27-36 in Measuring Human Trafficking - Complexities and Pitfalls, edited by E.U. Savona and S. Stefanizzi. New York: Springer.

Kapernick, David. 2012. "Shocking Finding: Women used as sex slaves in Melbourne and Sydney," news.com.au (online), 02 October 2012,<http://www.news.com.au/national/traffickedwomen-forced-into-brothels/story-fndo4eg91226486787059>.

Laczko, Frank. 2007. "Enhancing Data Collection and Research on Trafficking in Persons." Pp. 37-44 in Measuring Human Trafficking - Complexities and Pitfalls, edited by E.U. Savona and S. Stefanizzi. New York: Springer.

Landini, Gregory. 2010. Russell. Florence, KY: Routledge.

Larsen, Jacqueline Joudo and Lauren Renshaw. 2012. "People Trafficking in Australia."(Trends and Issues in Crime and Criminal Justice, No 441). Canberra, ACT: Australian Institute of Criminology.

Lazos, Grigoris. 2007. "Qualitative Research in Trafficking - A Particular Case." Pp. 95-106 in Measuring Human Trafficking - Complexities and Pitfalls, edited by E.U. Savona and S. Stefanizzi. New York: Springer.

Lindquist, Johan. 2013."Beyond anti-anti-trafficking." Dialect Anthropol 37(2):319-323. http://dx.doi.org/10.1007/s10624-013-9310-5

Lyall, Kimina. 2003. "Police Lay First Sex Traffic Charges," The Australian, June 19, pp. 1-3.

Maltzahn, Kathleen. 2008. Trafficked. Sydney: University of New South Wales Press.

Newton, Phyllis J., Timothy M. Mulcahy and Susan E. Martin. 2008. "Finding Victims of Human Trafficking." Paper presented to the US Department of Justice, Washington.

Noaks, Lesley and Emma Wincup. 2004. Criminological Research Understanding Qualitative Methods. London: SAGE Publications.

O'Brien, Erin, Sharon Hayes and Belinda Carpenter. 2013. The Politics of Sex Trafficking: A Moral Geography. New York: Palgrave Macmillan. http://dx.doi.org/10.1057/9781137318701

O'Brien, Natalie and Elisabeth Wynhausen. 2003. "Canberra to Review Sex Slave Policing," The Australian, April 4, pp. 6-7.

O'Brien, Natalie and Elisabeth Wynhausen. 2003. "Sex Slaves May Get Witness Protection," The Australian, March 26, pp. 6-8.

Parliamentary Joint Committee on the Australian Crime Commission. 2004. Inquiry into the Trafficking of Women for Sexual Servitude. Canberra, ACT: Parliament of Australia.

Pearson, Elaine. 2007. "Australia." Pp. 28-61 in Collateral Damage: The Impact of Anti-Trafficking Measures on Human Rights around the World, edited by M. Dottridge. Bangkok: Global Alliance Against Traffic in Women.

Project Respect. 2004. 'One Victim of Trafficking is One Too Many': Counting the Human Cost of Trafficking: Cases of Trafficking in Australia Documented in Feb/March 2004. Collingwood, VIC: Project Respect. 
Project Respect. 2008. How Are Women Trafficked?<http:// projectrespect.org.au/our_work/trafficking/why_trafficking > (accessed on 17/08/2014).

Putt, Judy. 2007. "Human Trafficking to Australia: A Research Challenge." (Trends and Issues in Crime and Criminal Justice, No 338). Canberra, ACT: Australian Institute of Criminology.

Schloenhardt, Andreas and Jarrod Jolly. 2013. Trafficking in Persons in Australia. Sydney, NSW: LexisNexis.

Schloenhardt, Andreas and Rose Hunt-Walshe. 2012. "The Role of Non-Governmental Organisations in Australia's AntiTrafficking in Persons Framework". University of Western Australia Law Review 36:57-91.

Schloenhardt, Andreas, Genevieve Beirne and Toby Corsbie. 2009."Trafficking in Persons in Australia: Myths and Realities."Global Crime 10(3):224-47. http://dx.doi.org/10.1080/17440570903079931

Schloenhardt, Andreas, Genevieve Beirne and Toby Corsbie. 2009."Human trafficking and sexual servitude in Australia." UNSW Law Journal 32(1):27-49.
Segrave, Marie. 2005. "Surely something is better than nothing? The Australian response to the trafficking of women into sexual servitude in Australia." Current Issues in Criminal Justice 16(1):85-92.

Shaw, Meagan. 2003. "Police Team to Tackle Sex Slavery," The Age (Melbourne), October 14, pp. 4-7.

Skogan, Wesley G. 1977. "Dimensions of the Dark Figure of Unreported Crime." Crime \& Delinquency 23(1):41-50. http://dx.doi.org/10.1177/001112877702300104

Snajdr, Edward. 2013."Beneath the Master Narrative: Human Trafficking, Myths of Sexual Slavery and Ethnographic Realities." Dialect Anthropol 37(2):229-256. http://dx.doi.org/10.1007/s10624-013-9292-3

Steele, Sarah. 2007. "Trafficking in People: The Australian Government's Response." Alternative Law Journal 32(1):1821

Weitzer, Ronald. 2012."Sex Trafficking and the Sex Industry." Journal of Criminal Law \& Criminology 101(4):1337-70.

Weitzer, Ronald. 2013."Rethinking Human Trafficking." Dialect Anthropol 37(2):309-312. http://dx.doi.org/10.1007/s10624-013-9313-2

(c) 2014 Wise and Schloenhardt; Licensee Lifescience Global.

This is an open access article licensed under the terms of the Creative Commons Attribution Non-Commercial License (http://creativecommons.org/licenses/by-nc/3.0/) which permits unrestricted, non-commercial use, distribution and reproduction in any medium, provided the work is properly cited. 